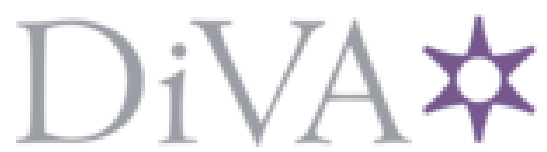

http://www.diva-portal.org

\title{
Postprint
}

This is the accepted version of a paper published in Journal of management. This paper has been peer-reviewed but does not include the final publisher proof-corrections or journal pagination.

Citation for the original published paper (version of record):

Patel, P C., Criaco, G., Naldi, L. (2018)

Geographic diversification and the survival of born-globals

Journal of management, 44(5): 2008-2036

https://doi.org/10.1177/0149206316635251

Access to the published version may require subscription.

N.B. When citing this work, cite the original published paper.

Permanent link to this version:

http://urn.kb.se/resolve?urn=urn:nbn:se:hj:diva-29792 


\title{
GEOGRAPHIC DIVERSIFICATION AND THE SURVIVAL OF BORN-GLOBALS
}

Accepted for publication in the Journal of Management

Please cite as: Patel, P. C., Criaco, G., \& Naldi, L. 2016. Geographic Diversification and the Survival of Born-Globals. Journal of Management, doi: 10.1177/0149206316635251

\author{
Pankaj C. Patel \\ Villanova University \\ Villanova School of Business \\ 800 Lancestar Ave. \\ Villanova, PA 19085 \\ Tel: (610) 519-4317 \\ Email: pankaj.patel@villanova.edu
}

\author{
Giuseppe Criaco \\ Jönköping International Business School \\ Center for Family Enterprise and Ownership - CeFEO \\ Email: giuseppe.criaco@ju.se
}

\section{Lucia Naldi}

Jönköping International Business School

Center for Family Enterprise and Ownership - CeFEO

Email: lucia.naldi@ju.se 


\title{
GEOGRAPHIC DIVERSIFICATION AND THE SURVIVAL OF BORN-GLOBALS
}

\begin{abstract}
The staged internationalization model posits that firms internationalize incrementally over time. However, born-globals are less likely to follow a more gradual model of staged internationalization, and they must decide on the scope of internationalization at their founding to exploit entrepreneurial opportunities on a global scale. Because returns from international expansion must be considered along with the risk of failure, we propose that born-globals' local industry conditions moderate the relationship between the scope of intraregional diversification (geographic diversification within a region) or interregional diversification (geographic diversification across different regions) and survival. Using a sample of 680 Swedish bornglobals founded in 2002, 2003, or 2004 and followed until 2010; data from Swedish Customs; and archival performance data, we find that interregional geographic diversification increases - and that intraregional diversification decreases - the likelihood of failure, which declines further when born-globals undertake intraregional geographic diversification under higher environmental dynamism in the home country industry. Conversely, undertaking interregional geographic diversification even when the home country industry is munificent increases the likelihood of failure (marginally significant). The findings are robust to several alternative specifications.
\end{abstract}

\section{INTRODUCTION}

According to the Uppsala model, internationalization is a gradual and incremental process that unfolds from an established domestic market (Johanson \& Vahlne, 1977). While the Uppsala model is generally applied to established firms that internationalize gradually over time, born-globals, or "young, entrepreneurial start-ups that initiate international business (typically exporting) soon after their inception" (Cavusgil \& Knight, 2015: 3), must devise an internationalization strategy upon founding. As noted by Almodóvar and Rugman (2014: 8), "[f]or born-globals, which are small, new, infant firms ... it is unrealistic to apply MNE [multinational enterprise] theory," as the international scope of venture opportunities does not lend itself to a gradual internationalization process. Taking a gradual approach is less meaningful for born-globals (cf. McDougall, Shane, \& Oviatt, 1994), which must be "ready out of the gate" to internationalize, thus rendering staged internationalization models less applicable to such firms. Bornglobals internationalize mainly through exporting (Almodóvar \& Rugman, 2014; Cavusgil \& Knight, 2015), and their geographic diversification efforts focus primarily on exports across countries or regions (Weiss, 2014). The extent of the geographic scope — concentrating in a region versus spreading across regions (Crick \& Jones, 2000) - is an important decision for born-globals. Sui and Baum (2014) noted the limited 
understanding of the international scope of small and medium-sized enterprises (SMEs) in the international entrepreneurship literature.

We propose a theoretical framework that explains the survival odds of born-global firms based on their international scope and the local industry conditions. The two dimensions of international scope are interregional geographic diversification, or a narrow international scope of exports focused on countries within a specific region, and intraregional geographic diversification, or a broad international scope of exports across regions.

The choice between a narrow or broad international scope is not straightforward. To lower the risk of failure, born-globals must maintain a dual focus on the scope of exports and local industry conditions. As Zander, McDougall-Covin, and Rose (2015) recently noted, the impact of local conditions in the home country on the internationalization of born-global firms needs to be better integrated into the existing theoretical and conceptual frameworks.

When the industry in the home country is highly dynamic (Dess \& Beard, 1984), higher intraregional geographic diversification could further increase the odds of survival. Dynamism refers to the degree, frequency, and unpredictability of change among local industry elements, while munificence consists of the extent to which the local industry provides enough resources to support firms and to enable them to grow and prosper (Castrogiovanni, 1991). Diffidence in expanding across regions when the home industry is munificent could limit the realization of the full potential of an entrepreneurial opportunity. In undertaking interregional geographic diversification, more munificent environments characterized by industry sales growth and greater resource availability (Yasai-Ardekani, 1989) could further increase the odds of survival. The proposed framework provides an extension of the popular staged internationalization framework and contributes to the international entrepreneurship literature.

\section{THEORY DEVELOPMENT AND HYPOTHESES}

Compared with MNEs, which pursue the staged internationalization model with a gradual and incremental internationalization strategy, born-globals aim to exploit entrepreneurial opportunities on a 
global scale and must decide on the scope of internationalization at their founding. Born-globals "exhibit a high degree of international entrepreneurial orientation [at] founding, and growth is supported by a distinctive entrepreneurial process, typically championed by founders or managers" (Cavusgil \& Knight, 2015: 4), and they seek to derive a substantial proportion of their revenue from exports (Cavusgil \& Knight, 2015; Coviello, 2015; Knight \& Cavusgil, 2004; Zander et al., 2015).

The Uppsala model (Johanson \& Vahlne, 1977), as the staged internationalization model is sometimes referred to, is one of the most widely cited models of internationalization for larger and established firms (Vahlne \& Johanson, 2013). The staged model of internationalization assesses the degree of internationalization along two dimensions: mode of operation and market of operation (Figueira-de-Lemos, Johanson, \& Vahlne, 2011). Mode of operation ranges from lower levels of commitment through exports to increasing levels of commitment through establishing foreign sales subsidiaries and production facilities. Market of operation, or scope, refers to countries or regions where a firm operates. Increasing commitment across different countries and regions indicates higher levels of internationalization. The Uppsala model states that firms internationalize gradually to reduce uncertainty. Initially, firms begin with a lower commitment and focus on fewer countries; however, as they learn more about a region or a country, they increase their commitment. The gradual model of internationalization has been used widely by established firms aiming to internationalize over time (Vahlne \& Johanson, 2013).

Born-globals face more variegated internationalization challenges than larger and moreestablished firms, and these unique internationalization patterns of born-globals have led to the development of international entrepreneurship as a distinct field of research (McDougall et al., 1994; Zahra 2005). Focused on rapid internationalization, born-globals are less likely to take the route of gradual reduction in uncertainty through staged internationalization, and their internationalization patterns deviate from the Uppsala model (Mathews \& Zander, 2007). Born-globals aim to exploit opportunities with a shorter product life cycle on a global scale (Boter \& Holmquist, 1996). Endowed with limited resources and facing closing windows of opportunity, born-globals must "be ready out of the gate" to internationalize (Oviatt \& McDougall, 2005). Because entrepreneurs must overcome the risk of failure in early stages of internationalization, as opposed 
to prescriptions of gradual uncertainty mitigation in the staged internationalization model, entrepreneurs of born-globals engage in the "discovery, enactment, evaluation, and exploitation of opportunities - across national borders - to create future goods and services" (Oviatt \& McDougall, 2005: 7). While the degree of commitment (or mode of operation) could be lower because most born-globals focus on exporting (Coviello, 2015; Madsen \& Servais, 1997; Moen \& Servais, 2002; Uner, Kocak, Cavusgil, \& Cavusgil, 2013), the second dimension of the Uppsala model, international scope, remains an important decision point for bornglobals.

\section{Failure Risk Among Born-Globals}

Because most ventures fail during their early years (Mata \& Portugal, 1994), the overall objective of a born-global is to manage the risk of failure. Although we do not propose the minimization of failure risk, born-globals must consider both risk and returns - taking into account possible opportunities for gain in commercializing on a global scale (i.e., the scope of internationalization). Related to the two aspects of international scope - interregional geographic diversification and intraregional geographic diversificationregions can be defined in a variety of ways, from economic, social, cultural, institutional, or geographic perspectives (for a recent review, see Flores, Aguilera, Mahdian, \& Vaaler, 2013). In this research, we adopt a geographic conceptualization of a region based on the physical continuity and proximity of the countries in the grouping (Arregle, Beamish, \& Hébert, 2009; Arregle, Miller, Hitt, \& Beamish, 2013).

Taking a diffident approach by focusing on a region, as the staged internationalization model would suggest, could have a significant opportunity cost and may even increase the likelihood of failure because a born-global may fail to cement its strategic position with a broader international scope. Conversely, taking too aggressive of an approach by increasing the scope of internationalization could spread a born-global's limited resources too thin and lead to failure. Thus, managing the cost-benefit trade-off in decisions about international scope at founding could decrease the risk of failure (Mudambi \& Zahra, 2007).

The failure risk of international scope decisions may also depend on the home industry conditions (cf. S. Andersson \& Florén, 2008). Considering the home industry conditions is important because at founding, 
a born-global could manage its failure risk through homeostasis of risk (cf. Wilde, 1982). Local industry conditions may add constraints (under home industry dynamism) or increase buffers (under home industry munificence). Dynamism is the degree, frequency, and unpredictability of change among industry elements (Dess \& Beard, 1984). Munificence is the degree to which local industry provides resources to support firms and enables them to grow and prosper (Castrogiovanni, 1991). Although industry conditions are influenced by global trends, local industry environments continue to be important for international activities (Buckley \& Ghauri, 2004; Zander et al., 2015). Following prior research (H. Kim, Hoskisson, \& Lee, 2015; Thomas, 2004), our study suggests that born-global firms are nested in their local industry environment and that such local industry conditions have an effect on the failure risks of international scope decisions.

In Table 1, we present a summary of benefits and costs related to inter- and intraregional geographic diversification. While intraregional diversification increases risk related to "putting all eggs in one basket" and limits arbitrage opportunities to countries in a region, it also lowers export costs. For born-globals facing risk of failure, lower costs from intraregional diversification could lower such risk. Conversely, interregional diversification lowers risk by exporting across regions and providing more arbitrage opportunities across countries in different regions, but it may also increase costs. While interregional diversification could benefit MNEs, higher costs could significantly increase risk of failure for a born-global. Next, we hypothesize the effects of the benefits and costs of intra- and interregional diversification and the conditional effects of the industry. ${ }^{\mathrm{i}}$

\section{Hypothesis Development}

\section{Intraregional Geographic Diversification and Born-Global Survival}

In attempting to launch a product on a global stage, typically through exporting, a born-global must process information related to understanding government policies and cultural and market requirements and develop an assessment of local economic and political risk. In addition to developing these sets of information for each country, it must aggregate, collate, and interpret this information to develop a portfolio of export markets. With an increasing international scope, born-globals must acquire competitor and 
customer-related information and establish contacts and relationships. Export-related costs include search, negotiation, monitoring, and enforcement costs (Trabold, 2002; Williamson, 1985). Different conditions in a country affect the organization of such relationships and require significant early investments by bornglobals (Hashai, 2011). As Reid (1983: 46) explained, if export markets differ in their accessibility, location, dispersion and purchasing behavior, costs "may increase by geometric proportions as firms continue market expansion."

As emerging ventures aiming to gain a foothold in export markets, born-globals aim to realize scope economies that lower the average costs of exporting. According to Holcomb, Holmes, and Hitt (2006: 554), "scope economies are present when resources shared across product and geographic markets result in a reduction of average costs." Because the scale of exports is generally smaller in early stages of internationalization, scale economies are rarely pursued by born-globals. Because demand is low during early stages and because born-globals must make initial R\&D and capital outlays and incur fixed costs of exporting, economies of scope are at the center stage of the scope of international diversification (Clerides, Lach, \& Tybout, 1998). Intraregional diversification could help lower initial costs and ease the leverage of resources across related economic, institutional, and cultural environments of countries in a region. While there are definitely costs of managing exports among countries within a region, costs could be relatively higher for interregional diversification. Bailey and Friedlaender (1982) found that (a) the reduction in average costs due to intraregional diversification results from the sharing of intangible assets-for example, information - between different countries within a region, (b) the reuse of an input in more than one market within a region (e.g., logistical arrangements), (c) the presence of a fixed factor of production (e.g., distribution channel) that is not fully utilized when selling to a single market within a region, and (d) economies of networking in related regions (e.g., warehouses can be located in one place and shipments dispersed to neighboring countries).

Intraregional geographic diversification facilitates coordination and communication among related markets in a region (Vachani, 1991) and eases flow in products and spillovers among countries in a region to allow born-globals to improve performance through lower costs resulting from "the cultural, cognitive, 
and normative similarities among countries in a region" (Qian, Li, \& Rugman, 2013: 637). Greater economic integration through trade agreements, similarities in sociocultural values, institutional congruence, and geographic proximity lower the average costs of pursuing internationalization in a region (Davidson, 1980).

For exporting firms, average costs of information processing are reduced, transportation and logistics costs are highest, and controlling inventory costs is a priority. By focusing on countries in a region, export forecasts could be improved and transportation costs lowered by spreading small export volumes across related markets and lowering average costs. Achieving small export volumes in each market allows for reduced transportation costs by shipping to the region in bulk and splitting the shipments. Related to logistics costs, as the global transportation industry is concentrated among firms that specialize in transportation to specific regions (Midoro, Musso, \& Parola, 2005), logistics costs could be further lowered by developing relationships with logistics firms specializing in regions. As narrow geographic scope allows for a more focused absorption of experiences and knowledge ( $\mathrm{L}$. Li \& Ng, 2002), born-globals can focus their attention on further understanding the regional markets and therefore identify means to lower costs. By concentrating limited resources on promotion and distribution, born-globals are better able to realize higher returns. In certain cases where there are returns, reverse supply-chain costs could be better contained when returns are aggregated from geographically closer countries. In other cases, where postsales service is necessary (Czinkota \& Ronkainen, 2003), intraregional diversification could lower postsales costs.

There is an opportunity cost of not engaging in interregion diversification. Oviatt and McDougall (1994) proposed that born-global firms are unfettered by the staged internationalization processes followed by MNEs and that their resources allow them to diversify across international settings. A strong intraregional focus could lead to missed opportunities (L. Li \& Qian, 2005); however, the likelihood of exploiting opportunities across regions is limited for a small born-global firm. With the limited resources available to a born-global, focusing on a better return-risk profile within a region is necessary to lower failure risk. For example, a born-global firm studied by Autio, George, and Alexy (2011) overestimated the maturity of the market in accepting its technology and made substantial investments that had to be written off. The firm then had to be more careful in subsequent market entries. Similarly, although arbitrage opportunities may 
exist across regions (Kogut, 1985), a limited resource base and liabilities of newness could limit the possibility of emergence of such arbitrage opportunities for a new born-global. Intraregional diversification allows for scope economies (Geringer, Tallman, \& Olson, 2000) that lead to specialized assets and resources and amortize costs across a manageable set of related markets in an intraregional setting. Intraregional diversification exposes the firm to a manageable diversity of cultural, economic, and institutional environments. While economic and political risks may spread through countries in a region more rapidly, the reduced risk mitigation from intraregion export diversification could substantially reduce average costs.

Focusing on a cluster of countries in a region allows for economizing on scope by spreading initial costs, setting up exchange and control mechanisms, and establishing communication and coordination channels among countries in a cluster that share similar characteristics (Nooteboom, 1993). Accordingly, we propose the following hypothesis:

Hypothesis 1: Intraregional geographic diversification lowers the hazard of failure for a born-global.

\section{Interregional Geographic Diversification and Born-Global Survival}

The broader literature on international diversification performance has highlighted the benefits of greater scope. Interregional geographic diversification allows a born-global firm to maximize market opportunities (Qian et al., 2008: 639), accumulate resources, and amortize costs by exploiting opportunities across diverse export markets. For born-globals with a short window of time to exploit opportunities (Guay \& Kothari, 2003), interregional diversification can lower the risk by maximizing exposure to these firms' products in a wide range of markets. Interregional diversification could provide the necessary learning opportunities to develop a bundle of international resources.

However, entering diverse export market regions also imposes significant transportation and logistics costs, particularly in the area of handling physical flows and documentation procedures. As noted by Reid (1983: 46), "Shipment methods, transportation scheduling and documentation procedures are likely to be market specific and can consume considerable administrative and clerical time.” In addition, born-global 
firms cannot readily change transportation and logistics arrangements, even when performance is unsatisfactory (Klein, 1989; Sys, 2009). Each country cluster may also require adjustments to the firm's products, which can lead to increases in average costs. Transportation and logistics costs also increase across regions.

Even in a sample of MNEs, Rugman and Verbeke (2004) found that the liabilities of interregional geographic diversification are greater than those of intraregional geographic diversification. In particular, diversification across different country clusters can increase the costs of managing sales in diverse economic, social, cultural, and institutional settings (Burgman, 1996; Reeb, Kwok, \& Baek, 1998). Goerzen and Beamish (2003) found that greater dissimilarities between country profiles increase the costs required to understand and respond to local demands. Born-globals with limited knowledge and learning routines may be unable to manage increasing cultural and institutional distances. Studies by Eriksson, Johanson, Majkgard, and Sharma (1997) and Sapienza, Autio, George, and Zahra (2006) propose higher failure rates for international firms with a broader scope than for international firms with a narrower scope. Despite the prospects for revenue increases (Shrader, Oviatt, \& McDougall, 2000), increasing commitment and complexity due to intraregional diversification increases the risk of failure.

Considering the above arguments, we propose that interregional geographic diversification increases the risk of failure.

Hypothesis 2: Interregional geographic diversification increases the risk of failure for a born-global.

\section{Home Industry Conditions and Geographic Diversification}

Environmental dynamism. Continuing the previous discussion related to Hypothesis 1, dynamic home country industry environments are associated with the unpredictability of customers and competitors and high rates of change (Dess \& Beard, 1984). The ephemeral nature of the opportunities in dynamic environments does not encourage large fixed-asset investments to realize economies of scale (rendering cost gains from economies of scale secondary; M. Li \& Simerly, 2002) and requires rapid exploitation (cf. 
Merton, 1973) that is more feasible in intraregional diversification, where a born-global can focus its limited resources. Increasing international scope when local industry is more dynamic increases uncertainty and exacerbates the risk of failure. Intraregional diversification affords a focused market to exploit opportunities that may be increasingly ephemeral in the dynamic home industry, thus allowing born-globals to manage failure risk by straddling this risk in both home and regional environments.

Intraregional geographic diversification allows born-globals to expand their product market so they can break even more rapidly and recoup their investments (Chang, 2007; Rugman \& Verbeke, 2004). Increasing intraregional diversification at higher levels of home industry dynamism also allows for cost control by lowering costs of understanding export requirements, transportation costs, and logistics costs in related markets within a region. Because dynamism in the home country demands greater managerial attention, higher levels of intraregional diversification allow born-globals to lower managerial informationprocessing challenges. Overall, with greater environmental dynamism, higher levels of intraregional geographic diversification provide a safety net for born-globals in context of home industry dynamism.

Hypothesis 3: When environmental dynamism in the home country industry is high, the risk of failure is lower for born-globals engaging in intraregional geographic diversification.

Environmental munificence. Continuing from Hypothesis 2, we posit that home industry munificence could allow born-globals to seek higher returns despite greater risk from interregional diversification. Higher levels of munificence increase the availability of resources to absorb higher costs of navigating interregional markets (Zaheer \& Mosakowski, 1997). Higher munificence in the home industry allows for the absorption of increased transportation costs (Chetty \& Campbell-Hunt, 2003).

Under home industry munificence, diffident intraregional strategies decrease a born-global's ability to develop strong competitive positions. Creating a larger footprint, despite the possible increase in costs, could lower the amount of long-term competition (cf. Ghemawat \& del Sol, 1998) and reduce direct and indirect internationalization costs in the long term (Sleuwaegen \& Onkelinx, 2014). A lower international scopedespite a growing home market — not only censors potential opportunities that a born-global seeks to exploit 
but also increases opportunity costs resulting from missed opportunities. Taking advantage of munificence in the home country industry to pursue interregional diversification breeds asset mass efficiencies (Dierickx \& Cool, 1989) that can strengthen the competitive position of a born-global. Thus, we posit the following:

Hypothesis 4: When environmental munificence in the home country industry is high, the risk of failure is lower for born-globals engaging in interregional geographic diversification.

\section{DATA AND METHODS}

\section{Sampling Strategy}

To test the proposed framework, the sampling strategy focuses on (a) identifying only born-globals, (b) limiting survivor bias by following born-globals from their 1st year of founding, and (c) lowering common-method variance by drawing on archival performance data. Studies have used various definitions of born-global firms, ranging from early-stage exporting efforts (McNaughton, 2003) to older and more established firms, such as those undergoing IPOs (McDougall, Oviatt, \& Shrader, 2003; Shrader et al., 2000). Over time, successful born-global ventures transition into long-term exporters or enduring global firms (Peiris, Akoorie, \& Sinha, 2012). However, ventures are unlikely to have substantial global operations in their 1st year of operation, and including only such ventures in the sample increases selection bias due to the unique resources endowed to ventures with both global operations and sales during the 1st year of establishment. Because a large body of prior work in international entrepreneurship has focused on "born exporters" as a sampling frame (Jones, Coviello, \& Tang, 2011), we consider only ventures with internationalization activity or exports during the year of establishment. To lower survivor bias, we track born-global ventures beginning in the year of establishment. To avoid common-method bias in reporting firm activities and performance, we rely on archival data of firm activities. 
Sampling Process

Our data are derived from two longitudinal databases maintained by Statistics Sweden: The first contains yearly data on all firms registered in Sweden (Registerbaserad arbetsmarknadsstatistik [RAMS]), and the second consists of trade data and provides yearly customs data for all firms registered in Sweden (Swedish Central Bureau of Statistics’ Exporter Register).

We use the first data set to identify all privately owned Swedish firms established during 2002, 2003, or 2004. Because these data contain complete information for the entire population of Swedish firms, we identify and track all born-global ventures from their inception (Fan \& Phan, 2007; Oviatt \& McDougall, 1994, 2005). We follow these firms until 2010. To control for cohort effects, we include year dummies, with 2002 as the reference year.

We focus on born-globals in the manufacturing sector (Qian, Khoury, Peng, \& Qian, 2010; Rugman, 2005), as service ventures are substantially different from manufacturing ventures in terms of their ability to provide services internationally, their input-output conversion processes, and their higher ratio of intangible assets. We also exclude from our sample firms owned by a foreign company or by a business group. Finally, we exclude all born-globals with more than 10 employees at founding because these firms are assumed to be reorganizations of activities that previously took place at an incumbent firm in Sweden (Andersson \& Klepper, 2013) or were more likely to have unique prefounding resource endowments. The final panel contains 2,686 observations from 680 born-global ventures, that is, new organizations established between 2002 and 2004 and followed until 2010.

\section{Sample Description and Operationalization of Regions}

Table 2 presents a description of the sample representing 23 manufacturing industries. The average hazard rate is $55.00 \%$, with firms in NACE codes 19 (manufacture of coke and refined petroleum products) and 21 (manufacture of basic pharmaceutical products and pharmaceutical preparation) all experiencing failure. The lowest level of interregional geographic diversification was experienced by firms involved in the printing and reproduction of recorded media and the manufacture of coke and refined petroleum products 
(0.00; SIC codes 18 and 19), whereas the highest level of interregional geographic diversification was experienced by firms involved in the manufacture of leather and related products and the manufacture of basic pharmaceutical products and pharmaceutical preparation (0.40; SIC codes 15 and 21). Firms involved in the manufacture of leather and related products have the highest level (0.23) of intraregional geographic diversification, and firms involved in the printing and reproduction of recorded media and the manufacture of coke and refined petroleum products $(0.00)$ have the lowest intraregional geographic diversification.

Regions are conceptualized in geographic terms and defined as groupings of countries with physical continuity and proximity (Arregle et al., 2013). We use a primarily geographic conceptualization of regions. Geographic distance directly affects the costs of coordination and transportation and influences the monitoring of changes within and outside the organization (Elango, 2004). Further, geographic proximity is a commonly used criterion for regional grouping (Flores et al., 2013: 454), and geography-based classifications are compatible with prior studies (Qian et al., 2010). In addition, unlike other classifications, geographic classifications are rather stable over time (Boehe, 2014). We grouped countries into nine geographic regions based on the partition of worldwide regions provided by prior export studies (Boehe, 2014; Trabold, 2002). Our regional grouping is also in line with the region classification proposed by Statistics Sweden and the United Nations.

Table 3 presents the average diversification of born-globals in industries across the nine regions in the study: North America, Western Europe, Northern Europe, Eastern Europe, Middle East, Far East and Central Asia, South and Central America, Africa, and Oceania. The values listed are average exports by industry in Swedish crowns.

Variables

\section{Dependent Variable}

Failure. Using 1 year as the primary time unit, we track venture survival until the year 2010, over a minimum of 6 years for ventures established in 2004 to a maximum of 8 years for ventures established in 
2002. Ventures that failed within the observation period are coded as 1 , whereas those that survived until 2010 are coded as 0 . To control for different entry rates, we control for the founding year.

\section{Independent Variables}

Unless stated otherwise, all independent variables and control variables are lagged at $\mathrm{t}-1$ to assess their effects on the venture's risk of failure at time t.

Geographic diversification. The trade data from Statistics Sweden provide the yearly export and import values of all products at the eight-digit product classification level. This database is then aggregated to firms' total exports and imports shipped between Sweden and other countries. Intraregional or intraregional geographic diversification is measured as follows (Boehe, 2014; Qian et al., 2008, 2010; Vachani, 1991):

$$
\text { Intra - region geographic diversification }=\sum_{r=1}^{R} p_{r} \sum_{c \in a} p_{c r}^{r} \ln \left(\frac{1}{p_{c r}^{r}}\right)
$$

where $p_{c r}^{r}=\frac{p_{c r}}{p_{r}}$ and $p_{c r}$ is the proportion of a firm's foreign sales in country $c$ in region $r$ and $p_{r}$ is the proportion of sales in region $r$. The first summation refers to the concentration of sales across countries within a region, and the second summation refers to the concentration of sales across regions. For the regional breakdown, this study adopts a classification consisting of nine regions (North America, Western Europe, Scandinavia, Eastern Europe, Middle East, Far East and Central Asia, South and Central America, Africa, and Oceania). This geography-based regional classification is in line with that of prior studies (Hitt, Hoskisson, \& Kim, 1997; Qian et al., 2008, 2010) and builds on prior work on geographic diversification (Berry, Guillén, \& Zhou, 2010). Moreover, in contrast to criteria in alternative country classifications (e.g., based on macroeconomic criteria), geographic regions are stable over time (Boehe, 2014).

Interregional or interregional geographic diversification is measured as follows (Boehe, 2014; Qian et al., 2008, 2010; Vachani, 1991):

$$
\text { Inter - region geographic diversification }=\sum_{r=1}^{R} p_{r} \ln \left(\frac{1}{p_{r}}\right)
$$


where $p_{r}$ is the sales attributed to region $r$. The values for intraregional diversification range from 0 to 1.49, while the values for interregional diversification range from 0 to 1.83 , and higher values indicate a higher degree of diversification. To reduce the effects of collinearity in our final analyses, we orthogonalized both variables, that is, inter- and intraregional geographical diversification, with the modified GramSchmidt procedure ("orthog" command in Stata), which removes common variance between transformed variables (Sine, Haveman, \& Tolbert, 2005), such that these variables are uncorrelated. ${ }^{\text {ii }}$

Industry dynamism (home country). The industry dynamism measure is for the born-global's industry in Sweden. Industry dynamism, defined as the level of instability (Boyd, 1990) in the industry in Sweden, is calculated as the standard error of the regression slope of a Swedish industry's (based on the four-digit NACE code) net sales over a 5-year period prior to the year of reference (Dess \& Beard, 1984; Heeley, King, \& Covin, 2006).

Industry munificence (home country). The industry munificence measure is for the born-global's industry in Sweden. Industry munificence, defined as the abundance of resources in the industry in Sweden, is calculated as the beta coefficient of the net sales regression equation used to calculate industry dynamism.

\section{Control Variables}

We use a series of time-varying and time-constant controls at the firm and industry levels. We control for industry by using two dummy variables, medium-high-tech and high-tech industries (EUROSTAT, 2016), with low-tech industry as the reference category. Because past performance can affect survival and future internationalization efforts, we include operating profit and sales. We also control for international experience, which is measured as the percentage of employees on the founding team who worked in another international venture in the 2 years prior to founding. A rapid pace of internationalization could lower the risk of failure by allowing for "learning advantages of newness" (Autio, Sapienza, \& Almeida, 2000), or it could increase the risk of failure by increasing time compression diseconomies (Vermeulen \& Barkema, 2002). To control for the pace of learning and resource accumulation, we control for internationalization speed, which is measured as the number of countries to which a born-global exported in a given year. 
Because this measure is a time-varying variable, changes in countries exported to each year proxy for speed. We also control for geographic distance, which is measured as the distance from Stockholm to the capital of the country to which the born-global venture exports. We then average this score for the total number of countries. As export activities of a born-global are influenced by worldwide export activity in an industry, we control for world industry trade volume (Wiersema \& Bowen, 2008) based on annual data on world industry exports and world industry imports derived from the World Bank's Trade and Production database (Nicita \& Olarreaga, 2007). We also control for home industry density, operationalized as the number of companies competing in the same industry (four-digit NACE) in the home country. Home industry competitor size is operationalized as the log of sales for firms in the home industry (four-digit NACE). Industry concentration is operationalized as 1 divided by the measure of the concentration of sales (summing the square of the sales market share of firms in the home country in a four-digit NACE sector; Bradley, Shepherd, \& Wiklund, 2011; Ndofor, Wesley, \& Priem, 2015). Lower values indicate greater monopolylike conditions because the available strategic options for new firms are reduced by larger firms that may control sales and distribution channels. Table 4 presents the means, standard deviations, and pairwise correlations.

\section{Analytical Strategy}

\section{Inverse Mills Ratios: Mergers and Splits}

Because firm survival is observed only in firms that were not merged or split, we correct for this selection bias. A popular method for correcting selection bias is the Heckman approach (Puhani, 2000). Wooldridge (1995) modified Heckman's approach to panel data models. The procedure involves two steps for calculating separate inverse Mills ratios for mergers and splits. In the first step, the selection equations are estimated with a standard probit regression for each time period $t=1,2, \ldots \mathrm{T}$, and the inverse Mills ratios are generated for each outcome (merger or split). In this first step, we include fixed assets and investments in machinery and equipment as predictors in the probit regressions. Both variables were significantly related to mergers and splits but not to survival. The inverse Mills ratios are constructed based 
on the estimates from the probit regressions. In the second step of the estimation, the matrix of the inverse Mills ratio defined for each time period is included in the original model, first, to correct for selection bias with the extended equation estimated using firm-specific fixed effects (the within estimator) and, second, to control for the problem of unobserved firm differences (our analysis employs firm-specific effects).

\section{Survival Model Specification}

We use a Cox regression, which does not assume a baseline hazard function. Following Hamilton and Nickerson's (2003) suggestion, we used the cluster option in Stata 13 to address autocorrelation and heteroskedasticity.

\section{RESULTS}

Table 5 presents the results of the Cox specification. The reported coefficients are odds ratios. An odds ratio above 1 indicates an increasing risk of failure, and an odds ratio below 1 indicates a decreasing hazard of failure. Model 1 in Table 5 presents a model that includes the controls, and Model 2 presents the direct effects of intra- and interregional geographic diversification. Hypothesis 1 predicted that intraregional geographic diversification lowers the risk of failure, which the results confirm (odds ratio $=0.80, \mathrm{p}<.05$; odds ratio below 1). Therefore, Hypothesis 1 is supported. Hypothesis 2 predicted that interregional geographic diversification increases the risk of failure, which is supported (odds ratio $=1.31, \mathrm{p}<.01$; odds ratio above 1). Hypothesis 3 proposed that under greater home country industry dynamism, born-global ventures undertaking intraregional geographic diversification have a lower risk of failure. This hypothesis is supported (Model 3, odds ratio $=0.77, \mathrm{p}<.01$ ). Figure 1 shows this result graphically—born-globals that operate in countries with highly dynamic home industries and that have increasing intraregional diversification realize higher survival rates.

With regard to the prediction of Hypothesis 4 that higher levels of interregional geographic diversification in increasingly munificent home country environments lower the risk of failure, we find significant effects in the opposite direction (Model 4, odds ratio $=1.11, \mathrm{p}<.10$; Model 5, odds ratio $=1.11$, $\mathrm{p}<.10$ ). Figure 2 shows that the likelihood of survival increases at a faster rate for born-globals with 
increasing interregional diversification in munificent environments. The direction and significance of the effects are consistent in the full model (Model 5). Overall, the results testing Hypotheses 1, 2, and 3 are consistent with the direction of the predicted effects. However, for Hypothesis 4, the predicted effect is marginally significant but in the opposite direction.

\section{Robustness Analysis}

To ensure the validity of our results, we assess whether the findings change under alternate model specifications.

\section{Self-Selection Into Internationalization}

We use a stringent definition considering only ventures with international sales in the 1 st year of establishment. Unobserved factors could drive the choice of internationalization, and firms seeking internationalization in the 1st year of operation may therefore be systematically different from firms that do not seek internationalization during their 1 st year. To control for these selection effects, we include an inverse Mills ratio and report the results in Table A1 (see online supplement). In the first-stage probit regression, with new ventures exporting in Year 1 coded as 1 and other new ventures established in the same year but not exporting coded as 0 , we use three predictors: two-digit NACE, sales, and employees. Including selfselection does not alter our estimates (Table A1: Hypothesis 1 , odds ratio $=0.81, \mathrm{p}<.05$; Hypothesis 2 , odds ratio $=1.31, \mathrm{p}<.001 ;$ Hypothesis 3 , odds ratio $=0.78, \mathrm{p}<.01 ;$ Hypothesis 4 , odds ratio $=1.11, \mathrm{p}<$ $.10)$.

\section{Alternate Interaction Specification}

We test for alternate interactions between intraregional diversification and industry munificence (Table $\mathrm{A} 2$, odds ratio $=0.97, \mathrm{p}>.10$ ) and an interaction between interregional diversification and industry dynamism $($ Table A3, odds ratio $=0.92, \mathrm{p}>.10)$. Neither effect was significant.

\section{Alternate Country Cluster Specification}


We run several models based on culture-based regional clusters and trade- and investment- based regional clusters. ${ }^{\text {iii }}$ The results also hold for this alternate cluster specification (Table A3 and Table A4), except that Hypothesis 4 was marginally significant in the main results.

\section{Controlling for Endogeneity}

It may be that born-globals do not select a diversification strategy at random but rather do so endogenously based on their characteristics and/or environmental factors. We control for endogeneity by implementing a two-stage residual inclusion model (see Terza, Basu, \& Rathouz, 2008) that is similar to the linear two-stage least squares estimator, except that in the second-stage regression, the endogenous variables are not replaced by first-stage predictors. Instead, first-stage residuals are included as additional regressors.

Research has shown that a firm's global expansion strategy and behavior can be mimetically affected by those of related firms, such as competitors, buyers, and affiliate firms within its industry group (e.g., Guillén, 2002; Henisz \& Delios, 2001). In our study, we choose mimetic global expansion as an instrumental variable. Theoretically, merely copying another firm's strategy without considering competitive advantage, that is, pursuing mimetic global expansion, is not likely to influence firm performance and survival directly (cf. H. Kim et al., 2015). Thus, in our study, we choose two instrumental variables (i.e., industry mimetic global expansion and location mimetic global expansion) that can potentially correct for endogeneity. In the first stage, we use these two instruments to predict born-globals' intra- and interregional diversification by using a tobit model. In the second stage, we include these variables' residuals as predictors of our dependent variable (see Terza et al., 2008), together with our independent variables. Our results in Table A5 are consistent with the main analysis.

\section{DISCUSSION}

Geographic diversification is studied mainly in the international business literature in the context of MNEs (Hitt, Tihanyi, Miller, \& Connelly, 2006; Rugman, 2005), and there is limited guidance on bornglobals' international scope at founding. The findings provide a "safety-first" guideline for born-globals: Intraregional diversification lowers the risk of failure, especially under home industry dynamism; in 
addition, pursuing interregional diversification under home industry munificence increases the odds of failure, albeit at marginally significant levels.

\section{Implications for International Entrepreneurship}

Even the smallest and youngest firms aspire to undertake international diversification (Shrader et al., 2000). International entrepreneurship scholars relate the success of born-global firms to their bold and aggressive postures in international markets, including a broad multimarket presence (Knight \& Cavusgil, 2004). Our results show, however, that interregional diversification strategies may be fatal for young ventures. We provide empirical evidence that entrepreneurs may devise "incorrect" geographic diversification strategies (Hitt, Ireland, Camp, \& Sexton, 2001), and we elucidate the gaps in understanding how, if at all, intraregional geographic diversification strategies might be beneficial for born-globals (Keupp \& Gassmann, 2009). In this respect, our findings are consistent with Almodóvar and Rugman (2014), who, for a sample of Spanish born-globals, found a negative relationship between export intensity and performance when more-experienced born-globals reduce their home region orientation to diversify into more distant regions.

The results also indirectly extend the work of Almodóvar and Rugman (2014) and the recent claims within the Uppsala tradition that "born-global firms are actually born-regional firms" (Johanson \& Vahlne, 2009; Lopez, Kundu, \& Ciravegna, 2009: 1228). Specifically, analysis shows that the risk of failure is also lower when born-globals choose to expand within a region, especially when home industry environment is dynamic. In line with Penrose's original diversification arguments, to survive in international markets, young firms need to develop an "area of [geographic] specialization" (Penrose, 1959/1995: 109).

Whereas past work on internationalization has focused on the role of embeddedness in home country geographic clusters to facilitate knowledge exchanges (Fernhaber, Gilbert, \& McDougall, 2008), we draw on and extend the role of home industry conditions. The role of the environment is based on contingency theory, and we propose that the home country industry is an important consideration in making internationalization decisions for born-globals. Although greater interregion diversification would seem 
advisable in a munificent environment, the results show that born-globals that undertake interregional diversification under high levels of environmental munificence are more likely to fail. Despite being in a munificent home industry, born-globals may face increased costs of absorbing resources from the home environment and of desorbing resources by transferring and leveraging such resources to diverse international markets (cf. Kumar, 2009; Xia, 2011). Thus, the availability of such slack resources in the home industry environment does not necessarily translate into success for born-globals in a foreign environment.

Recent work by Sui and Baum (2014) using 1,959 Canadian SMEs focused on the efficacy of bornglobals and the effects of gradual internationalization on survival. The authors found that although neither strategy is superior, born-global firms require more slack and innovation resources. We extend their work by assessing the extent of diversification strategies undertaken by born-global firms. In contrast to these authors' definition of born-regional firms as firms exporting to the U.S. market, Table 1 shows the diversity of regions exported by the firms in the current sample. We focus on born-global firms that have a broad international reach and use fine-grained measures of internationalization derived from archival data from Swedish customs. Whereas Sui and Baum used a coarse definition of regions ("1 if a firm exports to a specific region and 0 otherwise"; Sui \& Baum, 2014: 830), we rely on actual export data for nine regions.

Finally, our panel study has several advantages over prior research on born-globals, addressing repeated calls to overcome the limitations of the cross-sectional data used in most born-global studies (Jones et al., 2011; Keupp \& Gassmann, 2009). By choosing three cohorts of born-globals for our study, we assuage concerns regarding left censoring and selection bias in prior work. Additionally, our empirical focus on Swedish firms broadens the geographic scope of the study of international diversification beyond more conventional settings, such as the United States and Japan (Wan \& Hoskisson, 2003).

Whereas most international entrepreneurship research to date has focused on the antecedents of internationalization by young and small ventures (Keupp \& Gassmann, 2009), our study elucidates the survival implications of different types of internationalization strategies. Although survival is a key performance benchmark for ventures, very few studies have focused on the survival of born-globals 
(Coviello \& Jones, 2004; Coviello, McDougall, \& Oviatt, 2011). To our knowledge, our study is the first to draw inferences from a sample without survivor bias because we track ventures with an international presence from their 1st year of establishment.

\section{Implications for the International Business Literature}

The results emphasize that a firm's life-cycle stage (born-global vs. MNE) has important implications for firm performance. Although the effect of intra- and interregional diversification has been studied in the strategy context (e.g., Qian et al., 2010), the proposed model differs from these works in several dimensions. Beyond the studies on international expansion of MNEs, the international expansion patterns of born-global firms have seldom been studied. Whereas Qian et al. (2010) focused on the potential nonlinear effects of inter- and intraregional diversification in a cross-sectional sample of 123 public U.S. firms, the proposed longitudinal study based on 680 born-global Swedish ventures provides guidance on geographic expansion strategies under conditions of dynamism and munificence for a very different organizational form — a bornglobal firm — with very different priorities and constraints.

Our finding that intraregional diversification lowers the risk of failure contributes to the semiglobalization perspective (Rugman \& Verbeke, 2004), which suggests that geographic regions are an important level of analysis for understanding firms' internationalization strategies (Ghobadian, Rugman, \& Tung, 2014). The findings also inform both internationalization theory (Buckley \& Casson, 1976), which suggests that MNEs realize higher economies of scale and scope by explaining their intangible assets across countries, and multinational network theory, which suggests that MNEs arbitrage cross-country differences by developing a large network of production, sales, and subsidiaries (Kogut, 1985). Born-globals have limited technological knowhow, brand names, and managerial skills with which to develop a multinational network.

\section{Practical Implications}

Although geographic diversification is often presented as an essential vehicle for growth (Nachum, 2004), our study shows that only born-globals competing in dynamic home industry environments can 
enhance their likelihood of survival through an intraregional geographic diversification strategy concentrated within regional markets. By contrast, interregional geographical diversification is detrimental for born-globals, even in environments with high munificence. Thus, from a normative perspective, entrepreneurs in born-globals should be cautious about expanding their exports across different regions. Home industry munificence should not be construed as an opportunity for greater risk taking and aggressive international expansion because interregional geographic diversification under greater munificence could increase the likelihood of failure.

\section{Limitations and Future Research Directions}

The findings are not without limitations. First, we are unable to observe learning and resource allocation strategies in born-globals to further elucidate the development, implementation, execution, and control of international strategies. Elucidating the sequential and recursive process of internationalization could provide a better understanding of internationalization trajectories. We follow multiple cohorts of bornglobals to reduce survivor bias, and we rely on archival data to draw robust inferences; however, future research could use process data to identify how strategies, in addition to time-variant measures of intra- and interregional diversification, evolve in born-globals. Second, our definition of intra- and interregional geographic diversification is drawn from a rich stream of prior work (Rugman, 2005). Nevertheless, in addition to the geographic dimension of similarity among countries in a region, born-globals can devise diversification strategies based on countries that are similar or dissimilar in terms of economic, cultural, or institutional characteristics. It is likely that in addition to the geographic dimensions, relatedness based on economic, cultural, or institutional characteristics could be driven by the strategic goals of a born-global. For example, in service-related industries, diversification based on cultural similarities could be more advisable than focusing on scope-related advantages of geographic distance. Alternatively, a venture opportunity that may face legitimacy challenges could be better exploited by diversifying into related institutional environments. In addition to the direct costs of exports highlighted in the proposed framework, 
adjustment costs related to culture or mitigating legitimacy challenges could require different international diversification strategies.

Third, we draw on a sample of Swedish born-globals; therefore, the generalizability of our findings may be limited. Home country size could influence the motive to internationalize. For example, firms in China or the United States could have lower incentives to internationalize, as the size of the local market would be sufficient. Conversely, for relatively smaller markets, such as Sweden, the impetus to internationalize may be greater. Similarly, for ventures in developing countries, which exhibit low purchasing power, the allure of internationalizing may be greater.

Fourth, geographic diversification is also recognized as an operational hedge in the accounting, finance, and operations literature (Hendricks, Singhal, \& Zhang, 2009; Y. S. Kim, Mathur, \& Nam, 2006; Lee \& Makhija, 2009). Future studies could link operational hedging and born-global geographic diversification efforts. Research could explore the effects of formal and informal institutional conditions, including different industry conditions (Oliver, 1991). Fifth, our study indirectly documents the interregion and intraregion effects of the liability of foreignness with respect to born-globals' international expansion in the downstream value chain. For example, a born-global in Sweden might face fewer challenges in pursuing expansion to North America than in expanding into the Asia-Pacific region. Future studies could further explore the role of regional institutional distance to explain why some born-globals pursuing intraregional diversification survive and others do not. Despite a stream of literature on regionalization, there remains limited agreement on the boundaries of regions. Future research could explore the liability of foreignness in connection with other types of international operations in the upstream value chain, such as imports or international sourcing (Rugman \& Li, 2007).

\section{CONCLUSION}

A rarely explored question at the intersection of strategy and international entrepreneurship research concerns the "national versus regional versus global strategies" (Tallman \& Yip, 2009: 335) that bornglobals must pursue to improve firm performance. The proposed framework theorizes the relevance of local 
industry conditions in making decisions related to international scope. The staged internationalization model, which is focused on both commitment and scope, is less useful for born-globals. The findings highlight the "safety-first" guideline in making decisions on the export scope of a born-globalintraregional geographic diversification lowers the risk of failure, while interregional geographic diversification exacerbates the risk of failure. Irrespective of dynamism or munificence (marginally significant) in the home industry, intraregional diversification is preferred. Our findings thus extend the established strategy and international business frameworks on geographic diversification in the context of born-globals. 


\section{REFERENCES}

Almodóvar, P., \& Rugman, A. M. 2014. The M curve and the performance of Spanish international new ventures. British Journal of Management, 25: S6-S23.

Andersson, M., \& Klepper, S. 2013. Characteristics and performance of new firms and spinoffs in Sweden. Industrial and Corporate Change, 22: 245-280.

Andersson, S., \& Florén, H. 2008. Exploring managerial behavior in small international firms. Journal of Small Business and Enterprise Development, 15: 31-50.

Arregle, J.-L., Beamish, P. W., \& Hébert, L. 2009. The regional dimension of MNEs' foreign subsidiary localization. Journal of International Business Studies, 40: 86-107.

Arregle, J.-L., Miller, T. L., Hitt, M. A., \& Beamish, P. W. 2013. Do regions matter? An integrated institutional and semiglobalization perspective on the internationalization of MNEs. Strategic Management Journal, 34: 910-934.

Autio, E., George, G., \& Alexy, O. 2011. International entrepreneurship and capability developmentqualitative evidence and future research directions. Entrepreneurship Theory and Practice, 35: 1137.

Autio, E., Sapienza, H. J., \& Almeida, J. G. 2000. Effects of age at entry, knowledge intensity, and imitability on international growth. Academy of Management Journal, 43: 909-924.

Bailey, E. E., \& Friedlaender, A. F. 1982. Market structure and multiproduct industries. Journal of Economic Literature, 20: 1024-1048.

Berry, H., Guillén, M. F., \& Zhou, N. 2010. An institutional approach to cross-national distance. Journal of International Business Studies, 41: 1460-1480.

Boehe, D. M. 2014. Strategic hedging: Evidence from Brazilian exporters. Journal of World Business, 49: 290-300.

Boter, H., \& Holmquist, C. 1996. Industry characteristics and internationalization processes in small firms. Journal of Business Venturing, 11: 471-487.

Boyd, B. 1990. Corporate linkages and organizational environment: A test of the resource dependence model. Strategic Management Journal, 11: 419-430.

Bradley, S. W., Shepherd, D. A., \& Wiklund, J. 2011. The importance of slack for new organizations facing ‘tough' environments. Journal of Management Studies, 48: 1071-1097.

Buckley, P. J., \& Casson, M. 1976. The future of the multinational enterprise. London: Macmillan.

Buckley, P. J., \& Ghauri, P. N. 2004. Globalisation, economic geography and the strategy of multinational enterprises. Journal of International Business Studies, 35: 81-98.

Burgman, T. A. 1996. An empirical examination of multinational corporate capital structure. Journal of International Business Studies, 27: 553-570.

Castrogiovanni, G. J. 1991. Environmental munificence: A theoretical assessment. Academy of Management Review, 16: 542-565.

Cavusgil, S. T., \& Knight, G. 2015. The born global firm: An entrepreneurial and capabilities perspective on early and rapid internationalization. Journal of International Business Studies, 46: 3-16.

Chang, J. 2007. International expansion path, speed, product diversification and performance among emerging-market MNEs: Evidence from Asia-Pacific multinational companies. Asian Business \& Management, 6: 331-353.

Chetty, S., \& Campbell-Hunt, C. 2003. Paths to internationalisation among small- to medium-sized firms: A global versus regional approach. European Journal of Marketing, 37: 796-820.

Clerides, S. K., Lach, S., \& Tybout, J. R. 1998. Is learning by exporting important? Micro-dynamic evidence from Colombia, Mexico, and Morocco. Quarterly Journal of Economics, 113: 903-947.

Coviello, N. 2015. Re-thinking research on born globals. Journal of International Business Studies, 46: 17-26. 
Coviello, N. E., \& Jones, M. V. 2004. Methodological issues in international entrepreneurship research. Journal of Business Venturing, 19: 485-508.

Coviello, N. E., McDougall, P. P., \& Oviatt, B. M. 2011. The emergence, advance and future of international entrepreneurship research: An introduction to the special forum. Journal of Business Venturing, 26: 625-631.

Crick, D., \& Jones, M. V. 2000. Small high-technology firms and international high-technology markets. Journal of International Marketing, 8: 63-85.

Czinkota, M. R., \& Ronkainen, I. A. 2003. An international marketing manifesto. Journal of International Marketing, 11: 13-27.

Davidson, W. H. 1980. The location of foreign direct investment activity: Country characteristics and experience effects. Journal of International Business Studies, 11: 9-22.

Dess, G. G., \& Beard, D. W. 1984. Dimensions of organizational task environments. Administrative Science Quarterly, 29: 52-73.

Dierickx, I., \& Cool, K. 1989. Asset stock accumulation and sustainability of competitive advantage. Management Science, 35: 1504-1511.

Donnenfeld, S. 2003. Regional blocs and foreign direct investment. Review of International Economics, 11: 770-788.

Elango, B. 2004. Geographic scope of operations by multinational companies: An exploratory study of regional and global strategies. European Management Journal, 22: 431-441.

Eriksson, K., Johanson, J., Majkgard, A., \& Sharma, D. D. 1997. Experiential knowledge and cost in the internationalization process. Journal of International Business Studies, 28: 337-360.

EUROSTAT. 2016. Eurostat indicators on high-tech industry and knowledge-intensive services. Retrieved from http://ec.europa.eu/eurostat/cache/metadata/Annexes/htec_esms_an3.pdf

Fan, T., \& Phan, P. 2007. International new ventures: Revisiting the influences behind the "born-global" firm. Journal of International Business Studies, 38: 1113-1131.

Fernhaber, S. A., Gilbert, B. A., \& McDougall, P. P. 2008. International entrepreneurship and geographic location: An empirical examination of new venture internationalization. Journal of International Business Studies, 39: 267-290.

Figueira-de-Lemos, F., Johanson, J., \& Vahlne, J.-E. 2011. Risk management in the internationalization process of the firm: A note on the Uppsala model. Journal of World Business, 46: 143-153.

Flores, R., Aguilera, R. V., Mahdian, A., \& Vaaler, P. M. 2013. How well do supranational regional grouping schemes fit international business research models? Journal of International Business Studies, 44: 451-474.

Geringer, J. M., Tallman, S., \& Olson, D. M. 2000. Product and international diversification among Japanese firms. Strategic Management Journal, 21: 51-80.

Ghemawat, P., \& del Sol, P. 1998. Commitment versus flexibility? California Management Review, 40: 26-42.

Ghobadian, A., Rugman, A. M., \& Tung, R. L. 2014. Strategies for firm globalization and regionalization. British Journal of Management, 25: S1-S5.

Goerzen, A., \& Beamish, P. W. 2003. Geographic scope and multinational enterprise performance. Strategic Management Journal, 24: 1289-1306.

Guay, W., \& Kothari, S. P. 2003. How much do firms hedge with derivatives? Journal of Financial Economics, 70: 423-461.

Guillén, M. F. 2002. Structural inertia, imitation, and foreign expansion: South Korean firms and business groups in China, 1987-1995. Academy of Management Journal, 45: 509-525.

Hamilton, B. H., \& Nickerson, J. A. 2003. Correcting for endogeneity in strategic management research. Strategic Organization, 1: 51-78.

Hashai, N. 2011. Sequencing the expansion of geographic scope and foreign operations by "born global" firms. Journal of International Business Studies, 42: 995-1015.

Heeley, M. B., King, D. R., \& Covin, J. G. 2006. Effects of firm R\&D investment and environment on acquisition likelihood. Journal of Management Studies, 43: 1513-1535. 
Hendricks, K. B., Singhal, V. R., \& Zhang, R. 2009. The effect of operational slack, diversification, and vertical relatedness on the stock market reaction to supply chain disruptions. Journal of Operations Management, 27: 233-246.

Henisz, W. J., \& Delios, A. 2001. Uncertainty, imitation, and plant location: Japanese multinational corporations, 1990-1996. Administrative Science Quarterly, 46: 443-475.

Hitt, M. A., Hoskisson, R. E., \& Kim, H. 1997. International diversification: Effects on innovation and firm performance in product-diversified firms. Academy of Management Journal, 40: 767-798.

Hitt, M. A., Ireland, R. D., Camp, S. M., \& Sexton, D. L. 2001. Strategic entrepreneurship: entrepreneurial strategies for wealth creation. Strategic Management Journal, 22: 479-491.

Hitt, M. A., Tihanyi, L., Miller, T., \& Connelly, B. 2006. International diversification: Antecedents, outcomes, and moderators. Journal of Management, 32: 831-867.

Holcomb, T. R., Holmes, R. M., \& Hitt, M. A. 2006. Diversification to achieve scale and scope: The strategic implications of resource management for value creation. Advances in Strategic Management, 23: 549-587.

Johanson, J., \& Vahlne, J.-E. 1977. The internationalization process of the firm: A model of knowledge development and increasing foreign market commitments. Journal of International Business Studies, 8: 23-32.

Johanson, J., \& Vahlne, J. E. 2009. The Uppsala internationalization model revisited: From liability of foreignness to liability of outsidership. Journal of International Business Studies, 40: 1411-1433.

Jones, M. V., Coviello, N., \& Tang, Y. K. 2011. International entrepreneurship research (1989-2009): A domain ontology and thematic analysis. Journal of Business Venturing, 26: 632-659.

Keupp, M. M., \& Gassmann, O. 2009. The past and the future of international entrepreneurship: A review and suggestions for developing the field. Journal of Management, 35: 600-633.

Kim, H., Hoskisson, R. E., \& Lee, S. H. 2015. Why strategic factor markets matter: "New" multinationals' geographic diversification and firm profitability. Strategic Management Journal, 36: 518-536.

Kim, W. C., Hwang, P., \& Burgers, W. P. 1993. Multinationals' diversification and the risk-return tradeoff. Strategic Management Journal, 14: 275-286.

Kim, Y. S., Mathur, I., \& Nam, J. 2006. Is operational hedging a substitute for or a complement to financial hedging? Journal of Corporate Finance, 12: 834-853.

Klein, S. 1989. A transaction cost explanation of vertical control in international markets. Journal of the Academy of Marketing Science, 17: 253-260.

Knight, G. A., \& Cavusgil, S. T. 2004. Innovation, organizational capabilities, and the born-global firm. Journal of International Business Studies, 35: 124-141.

Kogut, B. 1985. Designing global strategies: Comparative and competitive value added chains. Sloan Management Review, 26: 15-28.

Kumar, M. S. 2009. The relationship between product and international diversification: The effects of short-run constraints and endogeneity. Strategic Management Journal, 30: 99-116.

Lee, S. H., \& Makhija, M. 2009. Flexibility in internationalization: Is it valuable during an economic crisis? Strategic Management Journal, 30: 537-555.

Leonidou, L. C. 2004. An analysis of the barriers hindering small business export development. Journal of Small Business Management, 42: 279-302.

Li, L., \& Ng, P. 2002. Market exchanges, hierarchical exchanges or relational exchanges in export channels into emerging markets. International Business Review, 11: 707-723.

Li, L., \& Qian, G. 2005. Dimensions of international diversification: Their joint effects on firm performance. Journal of Global Marketing, 18(3/4): 7-35.

Li, M., \& Simerly, R. L. 2002. Environmental dynamism, capital structure and innovation: An empirical test. The International Journal of Organizational Analysis, 10: 156-171.

Lopez, L. E., Kundu, S. K., \& Ciravegna, L. 2009. Born global or born regional? Evidence from an exploratory study in the Costa Rican software industry. Journal of International Business Studies, 40: $1228-1238$. 
Madsen, T. K., \& Servais, P. 1997. The internationalization of born globals: An evolutionary process? International Business Review, 6: 561-583.

Mata, J., \& Portugal, P. 1994. Life duration of new firms. Journal of Industrial Economics, 42: 227-245.

Mathews, J. A., \& Zander, I. 2007. The international entrepreneurial dynamics of accelerated internationalisation. Journal of International Business Studies, 38: 387-403.

McDougall, P. P., Oviatt, B. M., \& Shrader, R. C. 2003. A comparison of international and domestic new ventures. Journal of International Entrepreneurship, 1: 59-82.

McDougall, P. P., Shane, S., \& Oviatt, B. M. 1994. Explaining the formation of international new ventures: The limits of theories from international business research. Journal of Business Venturing, 9: 469-487.

McNaughton, R. B. 2003. The number of export markets that a firm serves: Process models versus the born-global phenomenon. Journal of International Entrepreneurship, 1: 297-311.

Merton, R. C. 1973. An intertemporal capital asset pricing model. Econometrica: Journal of the Econometric Society, 41: 867-887.

Midoro, R., Musso, E., \& Parola, F. 2005. Maritime liner shipping and the stevedoring industry: Market structure and competition strategies. Maritime Policy \& Management, 32: 89-106.

Moen, Ø., \& Servais, P. 2002. Born global or gradual global? Examining the export behavior of small and mediumsized enterprises. Journal of International Marketing, 10: 49-72.

Mudambi, R., \& Zahra, S. A. 2007. The survival of international new ventures. Journal of International Business Studies, 38: 333-352.

Nachum, L. 2004. Geographic and industrial diversification of developing country firms. Journal of Management Studies, 41: 273-294.

Ndofor, H. A., Wesley, C., \& Priem, R. L. 2015. Providing CEOs with opportunities to cheat the effects of complexity- based information asymmetries on financial reporting fraud. Journal of Management, 41: 1774-1797.

Nicita, A., \& Olarreaga, M. 2007. Trade, production, and protection database, 1976-2004. World Bank Economic Review, 21: 165-171.

Nooteboom, B. 1993. Firm size effects on transaction costs. Small Business Economics, 5: 283-295.

Oliver, C. 1991. Strategic responses to institutional processes. Academy of Management Review, 16: 145179.

Oviatt, B. M., \& McDougall, P. P. 1994. Toward a theory of international new ventures. Journal of International Business Studies, 25: 45-64.

Oviatt, B. M., \& McDougall, P. P. 2005. Defining international entrepreneurship and modeling the speed of internationalization. Entrepreneurship Theory and Practice, 29: 537-554.

Peiris, I. K., Akoorie, M. E., \& Sinha, P. 2012. International entrepreneurship: A critical analysis of studies in the past two decades and future directions for research. Journal of International Entrepreneurship, 10: 279-324.

Penrose, E. 1959/1995. The theory of the growth of the firm (3rd ed.). Oxford, UK: Oxford University Press.

Puhani, P. 2000. The Heckman correction for sample selection and its critique. Journal of Economic Surveys, 14: 53-68.

Qian, G., Khoury, T. A., Peng, M. W., \& Qian, Z. 2010. The performance implications of intra- and interregional geographic diversification. Strategic Management Journal, 31: 1018-1030.

Qian, G., Li, L., Li, J., \& Qian, Z. 2008. Regional diversification and firm performance. Journal of International Business Studies, 39: 197-214.

Qian, G., Li, L., \& Rugman, A. M. 2013. Liability of country foreignness and liability of regional foreignness: Their effects on geographic diversification and firm performance. Journal of International Business Studies, 44: 635-647.

Reeb, D. M., Kwok, C. C., \& Baek, H. Y. 1998. Systematic risk of the multinational corporation. Journal of International Business Studies, 29: 263-279. 
Reid, S. 1983. Firm internationalization, transaction costs and strategic choice. International Marketing Review, 1: 44-56.

Rugman, A. M. 2005. The regional multinationals: MNEs and "global" strategic management. Cambridge, UK: Cambridge University Press.

Rugman, A. M., \& Li, J. 2007. Will China's multinationals succeed globally or regionally? European Management Journal, 25: 333-343.

Rugman, A. M., \& Verbeke, A. 2004. A perspective on regional and global strategies of multinational enterprises. Journal of International Business Studies, 35: 3-18.

Sapienza, H. J., Autio, E., George, G., \& Zahra, S. 2006. A capabilities perspective on the effects of early internationalization on firm survival and growth. Academy of Management Review, 31: 914-933.

Shrader, R. C., Oviatt, B. M., \& McDougall, P. P. 2000. How new ventures exploit trade-offs among international risk factors: Lessons for the accelerated internationization of the 21 st century. Academy of Management Journal, 43: 1227-1247.

Sine, W. D., Haveman, H. A., \& Tolbert, P. S. 2005. Risky business? Entrepreneurship in the new independentpower sector. Administrative Science Quarterly, 50: 200-232.

Sleuwaegen, L., \& Onkelinx, J. 2014. International commitment, post-entry growth and survival of international new ventures. Journal of Business Venturing, 29: 106-120.

Sui, S., \& Baum, M. 2014. Internationalization strategy, firm resources and the survival of SMEs in the export market. Journal of International Business Studies, 45: 821-841.

Sys, C. 2009. Is the container liner shipping industry an oligopoly? Transport Policy, 16: 259-270.

Tallman, S., \& Yip, G. 2009. Strategy and the multinational enterprise. In A. Rugman (Ed.), The Oxford handbook of international business: 307-340. New York: Oxford University Press.

Terza, J. V., Basu, A., \& Rathouz, P. J. 2008. Two-stage residual inclusion estimation: Addressing endogeneity in health econometric modeling. Journal of Health Economics, 27: 531-543.

Thomas, L. G. 2004. Are we all global now? Local vs. foreign sources of corporate competence. The case of the Japanese pharmaceutical industry. Strategic Management Journal, 25: 865-886.

Trabold, H. 2002. Export intermediation: An empirical test of Peng and Ilinitch. Journal of International Business Studies, 33: 327-344.

Uner, M. M., Kocak, A., Cavusgil, E., \& Cavusgil, S. T. 2013. Do barriers to export vary for born globals and across stages of internationalization? An empirical inquiry in the emerging market of Turkey. International Business Review, 22: 800-813.

Vachani, S. 1991. Distinguishing between related and unrelated international geographic diversification: A comprehensive measure of global diversification. Journal of International Business Studies, 22: 307-322.

Vahlne, J.-E., \& Johanson, J. 2013. The uppsala model on evolution of the multinational business enterprise: From internalization to coordination of networks. International Marketing Review, 30: 189-210.

Vermeulen, F., \& Barkema, H. 2002. Pace, rhythm, and scope: Process dependence in building a profitable multinational corporation. Strategic Management Journal, 23: 637-653.

Wan, W. P., \& Hoskisson, R. E. 2003. Home country environments, corporate diversification strategies, and firm performance. Academy of Management Journal, 46: 27-45.

Weiss, A. 2014. Searching in a global environment: Finding information from and on foreign countries, regions and markets. Business Information Review, 31: 243-256.

Wiersema, M. F., \& Bowen, H. P. 2008. Corporate diversification: The impact of foreign competition, industry globalization, and product diversification. Strategic Management Journal, 29: 115-132.

Wilde, G. J. 1982. The theory of risk homeostasis: Implications for safety and health. Risk Analysis, 2: 209-225.

Williamson, O. E. 1985. The economic institutions of capitalism. New York: Simon and Schuster.

Wooldridge, J. M. 1995. Selection corrections for panel data models under conditional mean independence assumptions. Journal of Econometrics, 68: 115-132. 
Xia, J. 2011. Mutual dependence, partner substitutability, and repeated partnership: The survival of crossborder alliances. Strategic Management Journal, 32: 229-253.

Yasai-Ardekani, M. 1989. Effects of environmental scarcity and munificence on the relationship of context to organizational structure. Academy of Management Journal, 32: 131-156.

Zaheer, S., \& Mosakowski, E. 1997. The dynamics of the liability of foreignness: A global study of survival in financial services. Strategic Management Journal, 18: 439-464.

Zahra, S. A. 2005. A theory of international new ventures: A decade of research. Journal of International Business Studies, 36: 20-28.

Zander, I., McDougall-Covin, P., \& Rose, E. L. 2015. Born globals and international business: Evolution of a field of research. Journal of International Business Studies, 46: 27-35. 
Table 1

\section{Benefits of international scope}

Spread market risks (Kim, Hwang, \& Burgers,

1993)

Arbitrage across countries (Kogut, 1985)

\section{Costs of international scope}

Transportation and logistics costs, including supplying inventory in overseas markets. For exporting firms, these are among the highest costs (Leonidou, 2004)

\section{Provision of postsales services. The large}

geographic distance separating exporters from their foreign customers causes delays and increases costs in the provision of postsales services (Czinkota \&

Ronkainen, 2003) because company personnel have to visit overseas markets at regular intervals,

establish service stations in strategic locations, and maintain large quantities of spare parts.

Odds of failure

\section{Benefits and Costs of International Scope}

\section{Intra-regional}

It is beneficial, but market and political crises might spill over into neighboring countries.

Arbitrage possibilities are marginal across neighboring countries.

\section{Intra-regional}

These costs also exist when exporting to different countries within the same region, but they can be contained. For example, when exporting to neighboring countries (or countries within the same region), goods can be shipped to the same warehousing system and then distributed within the region. The same goes for resupplying.

These costs exist within regions, but they can be partly contained by establishing service stations in one strategic location in the region.

\section{Inter-regional}

Because problems in one country might spill over to neighboring countries, spreading market risks across regions can be more beneficial than doing so within one region.

Arbitrage is more possible with geographical distance across different regions.

\section{Inter-regional}

These costs may become very high, so there is a need for a multiple warehousing system.

These costs may become very high, so there is need for multiple strategic locations or for different solutions. 
Table 2

Cluster Measures of Sectors (Two-Digit NACE) Representing Born-Globals in Our Sample (Average Data Are Shown)

\begin{tabular}{|c|c|c|c|c|}
\hline Sector & $\begin{array}{l}\text { Number } \\
\text { of firms }\end{array}$ & $\begin{array}{c}\text { Hazard rate } \\
(\%)\end{array}$ & $\begin{array}{c}\text { Intra-regional } \\
\text { geographic } \\
\text { diversification }\end{array}$ & $\begin{array}{c}\text { Inter-regional } \\
\text { geographic } \\
\text { diversification }\end{array}$ \\
\hline 10 - Manufacture of food products & 20 & 0.55 & 0.09 & 0.04 \\
\hline 11- Manufacture of beverages & 6 & 0.67 & 0.03 & 0.10 \\
\hline 13 - Manufacture of textiles & 58 & 0.59 & 0.08 & 0.14 \\
\hline 14 - Manufacture of apparel & 12 & 0.50 & 0.09 & 0.16 \\
\hline 15 - Manufacture of leather and related products & 5 & 0.80 & 0.23 & 0.40 \\
\hline $\begin{array}{l}16 \text { - Manufacture of wood and of products of wood and cork, except } \\
\text { furniture; manufacture of articles of straw and plaiting materials }\end{array}$ & 61 & 0.57 & 0.04 & 0.04 \\
\hline 17 - Manufacture of paper and paper products & 29 & 0.48 & 0.04 & 0.07 \\
\hline 18 - Printing and reproduction of recorded media & 4 & 0.25 & 0.00 & 0.00 \\
\hline 19 - Manufacture of coke and refined petroleum products & 1 & 1.00 & 0.00 & 0.00 \\
\hline 20 - Manufacture of chemicals and chemical products & 28 & 0.46 & 0.18 & 0.25 \\
\hline $\begin{array}{l}21 \text { - Manufacture of basic pharmaceutical products and } \\
\text { pharmaceutical preparation }\end{array}$ & 1 & 1.00 & 0.13 & 0.40 \\
\hline 22 - Manufacture of rubber and plastic products & 39 & 0.49 & 0.11 & 0.15 \\
\hline 23 - Manufacture of other non-metallic mineral products & 24 & 0.42 & 0.15 & 0.25 \\
\hline 24 - Manufacture of basic metals & 7 & 0.29 & 0.08 & 0.05 \\
\hline $\begin{array}{l}25 \text { - Manufacture of fabricated metal products, except machinery } \\
\text { and equipment }\end{array}$ & 142 & 0.53 & 0.10 & 0.18 \\
\hline 26 - Manufacture of computer, electronic and optical products & 71 & 0.56 & 0.21 & 0.38 \\
\hline 27 - Manufacture of electrical equipment & 8 & 0.13 & 0.11 & 0.13 \\
\hline 28 - Manufacture of machinery and equipment n.e.c. & 91 & 0.51 & 0.15 & 0.23 \\
\hline 29 - Manufacture of motor vehicles, trailers and semi-trailers & 14 & 0.64 & 0.03 & 0.03 \\
\hline 30 - Manufacture of other transport equipment & 12 & 0.58 & 0.04 & 0.03 \\
\hline 31 - Manufacture of furniture & 8 & 0.63 & 0.12 & 0.24 \\
\hline 32 - Other manufacturing & 33 & 0.55 & 0.10 & 0.15 \\
\hline 33 - Repair and installation of machinery and equipment & 6 & 0.50 & 0.17 & 0.38 \\
\hline Sum/Mean & 680 & 0.55 & 0.10 & 0.17 \\
\hline
\end{tabular}

Note: $\mathrm{N}=2,686$ observations of 680 born-globals established in 2002, 2003, or 2004 and followed until 2010 . 
Table 3

Average Exports (Value of Goods in Swedish Crowns) by Firms Representing Born-Globals in Our Sample by Sector (Two-Digit NACE) and Region (Average Data Are Shown)

\begin{tabular}{|c|c|c|c|c|c|c|c|c|c|}
\hline Sector & $\begin{array}{c}\text { Region } 1 \\
\text { North } \\
\text { America }\end{array}$ & $\begin{array}{l}\text { Region } 2 \\
\text { Western } \\
\text { Europe }\end{array}$ & $\begin{array}{l}\text { Region } 3 \\
\text { Scandinavia }\end{array}$ & $\begin{array}{c}\text { Region } 4 \\
\text { Eastern } \\
\text { Europe }\end{array}$ & $\begin{array}{c}\text { Region } 5 \\
\text { Middle } \\
\text { East }\end{array}$ & $\begin{array}{c}\text { Region } 6 \\
\text { Far East and } \\
\text { Central Asia }\end{array}$ & $\begin{array}{c}\text { Region } 7 \\
\text { South and } \\
\text { Central } \\
\text { America } \\
\end{array}$ & $\begin{array}{l}\text { Region } 8 \\
\text { Africa }\end{array}$ & $\begin{array}{l}\text { Region } 9 \\
\text { Oceania }\end{array}$ \\
\hline 10 - Manufacture of food products & $216,300.00$ & $1,178,428.20$ & $418,024.92$ & $123,969.74$ & 0.00 & $350,087.50$ & 0.00 & 0.00 & 0.00 \\
\hline 11- Manufacture of beverages & $156,500.71$ & $364,683.90$ & $120,051.26$ & $77,161.14$ & $107,730.00$ & 270.00 & 0.00 & 0.00 & $15,312.00$ \\
\hline 13 - Manufacture of textiles & $172,482.98$ & $244,603.60$ & $125,611.22$ & $97,468.10$ & $8,056.00$ & $35,457.01$ & $22,071.44$ & $15,982.00$ & $31,984.07$ \\
\hline 14 - Manufacture of apparel & $90,822.93$ & $71,881.39$ & $147,375.35$ & $35,576.38$ & 0.00 & $14,152.60$ & $127,285.00$ & 0.00 & $5,881.00$ \\
\hline 15 - Manufacture of leather and related products & $54,249.59$ & $204,112.00$ & $22,081.14$ & $21,638.50$ & $96,554.00$ & $60,118.79$ & 0.00 & 0.00 & $46,781.67$ \\
\hline $\begin{array}{l}16 \text { - Manufacture of wood and of products of wood and cork, except } \\
\text { furniture; manufacture of articles of straw and plaiting materials }\end{array}$ & $30,896.29$ & $848,437.38$ & $249,474.74$ & $302,008.08$ & 0.00 & $2,277,032.60$ & $97,446.50$ & $7,886,360.80$ & $95,679.00$ \\
\hline 17 - Manufacture of paper and paper products & $17,554.46$ & $12,931.25$ & $126,228.60$ & $231,742.17$ & $138,066.00$ & $205,870.43$ & $42,500.00$ & 0.00 & $77,630.50$ \\
\hline 18 - Printing and reproduction of recorded media & $4,502.00$ & 0.00 & $59,341.07$ & $3,252.19$ & 0.00 & 0.00 & 0.00 & 0.00 & 0.00 \\
\hline 19 - Manufacture of coke and refined petroleum products & 0.00 & 0.00 & 0.00 & 0.00 & 0.00 & 0.00 & 0.00 & $17,638.00$ & 0.00 \\
\hline 20 - Manufacture of chemicals and chemical products & $768,116.31$ & $243,050.76$ & $684,955.18$ & $401,591.79$ & $97,958.25$ & $486,159.23$ & $83,579.33$ & $13,475.33$ & $54,570.10$ \\
\hline $\begin{array}{l}21 \text { - Manufacture of basic pharmaceutical products and } \\
\text { pharmaceutical preparation }\end{array}$ & 0.00 & $324,373.20$ & $87,272.20$ & $2,211,669.70$ & 0.00 & 0.00 & 0.00 & 0.00 & 0.00 \\
\hline 22 - Manufacture of rubber and plastic products & $281,553.66$ & $361,409.11$ & $311,787.98$ & $459,118.64$ & $53,225.83$ & $94,866.08$ & $18,132.57$ & 0.00 & $28,124.44$ \\
\hline 23 - Manufacture of other non-metallic mineral products & $323,762.34$ & $1,913,640.10$ & $51,064.16$ & $46,155.07$ & $153,680.23$ & $560,352.03$ & $126,472.00$ & $12,584.00$ & $10,067.54$ \\
\hline 24 - Manufacture of basic metals & 0.00 & 0.00 & $51,596.84$ & $84,700.00$ & 0.00 & 0.00 & 0.00 & $62,759.25$ & 0.00 \\
\hline $\begin{array}{l}25 \text { - Manufacture of fabricated metal products, except machinery } \\
\text { and equipment }\end{array}$ & $282,962.18$ & $805,759.13$ & $247,399.17$ & $376,500.92$ & $68,122.74$ & $167,476.79$ & $120,602.29$ & $111,082.78$ & $102,245.59$ \\
\hline 26 - Manufacture of computer, electronic and optical products & $589,102.68$ & $427,001.62$ & $150,185.03$ & $136,002.74$ & $109,529.26$ & $357,451.19$ & $304,892.98$ & $378,890.07$ & $96,597.91$ \\
\hline 27 - Manufacture of electrical equipment & $3,462.00$ & $10,688.00$ & $246,820.16$ & $94,889.30$ & $123,543.25$ & $204,334.17$ & $19,651.00$ & 0.00 & $22,868.00$ \\
\hline 28 - Manufacture of machinery and equipment n.e.c. & $715,363.54$ & $648,529.02$ & $202,971.91$ & $213,403.07$ & $159,898.12$ & $200,618.72$ & $69,245.17$ & $271,151.78$ & $176,413.48$ \\
\hline 29 - Manufacture of motor vehicles, trailers and semi-trailers & $44,252.83$ & $13,977.00$ & $146,826.91$ & $98,654.38$ & 0.00 & $1,868.80$ & 0.00 & 0.00 & 0.00 \\
\hline 30 - Manufacture of other transport equipment & $819,828.00$ & $1,902,022.80$ & $64,124.87$ & $7,500.00$ & $970,672.00$ & 0.00 & 0.00 & 0.00 & 0.00 \\
\hline 31 - Manufacture of furniture & $143,089.50$ & 560.00 & $97,703.68$ & $27,451.10$ & $8,956.00$ & $110,822.07$ & 0.00 & 0.00 & $39,743.29$ \\
\hline 32 - Other manufacturing & $58,170.94$ & $20,494.06$ & $83,158.44$ & $9,109.88$ & 0.00 & $39,003.17$ & 0.00 & $15,477.00$ & $3,119.00$ \\
\hline 33 - Repair and installation of machinery and equipment & $46,534.18$ & $1,153,518.30$ & $99,832.29$ & $22,513.91$ & $20,114.83$ & $36,395.79$ & 0.00 & 0.00 & $35,648.64$ \\
\hline Mean & $209,543.79$ & $467,395.69$ & $164,951.61$ & $220,959.86$ & $92,004.63$ & $226,188.56$ & $44,864.27$ & $381,973.96$ & $36,637.66$ \\
\hline
\end{tabular}


Table 4

Means, Standard Deviations, and Pairwise Correlations

\begin{tabular}{|c|c|c|c|c|c|c|c|c|c|c|c|c|c|c|c|c|c|}
\hline & Mean & S.D. & 1 & 2 & 3 & 4 & 5 & 6 & 7 & 8 & 9 & 10 & 11 & 12 & 13 & 14 & 15 \\
\hline 1. Failure & 0.13 & 0.34 & & & & & & & & & & & & & & & \\
\hline 2. Medium High-Tech Dummy & 0.24 & 0.43 & -0.04 & & & & & & & & & & & & & & \\
\hline 3. High-Tech Dummy & 0.11 & 0.31 & 0.01 & -0.19 & & & & & & & & & & & & & \\
\hline 4. Operating Profits & 350.21 & 666.13 & -0.16 & 0.04 & 0.05 & & & & & & & & & & & & \\
\hline 5. Sales & $6,078.76$ & $6,773.10$ & -0.19 & 0.03 & 0.02 & 0.60 & & & & & & & & & & & \\
\hline 6. International Experience & 0.62 & 0.40 & -0.10 & 0.06 & 0.10 & 0.11 & 0.25 & & & & & & & & & & \\
\hline 7. Internationalization Speed & 1.52 & 1.44 & -0.11 & 0.06 & 0.19 & 0.21 & 0.32 & 0.15 & & & & & & & & & \\
\hline 8. Geographic Distance & $1,996.40$ & $2,647.89$ & -0.04 & -0.02 & 0.20 & 0.09 & 0.12 & 0.07 & 0.61 & & & & & & & & \\
\hline 9. World Industry Trade Volume & 1.06 & 0.24 & 0.03 & -0.18 & 0.18 & -0.00 & -0.07 & 0.02 & 0.08 & 0.08 & & & & & & & \\
\hline 10. Industry Density (home country) & 789.30 & $1,077.67$ & 0.00 & -0.23 & -0.12 & 0.02 & 0.04 & 0.02 & -0.12 & -0.08 & -0.02 & & & & & & \\
\hline 11. Industry Competitor Size (home country) & 10.05 & 1.25 & -0.01 & 0.33 & 0.34 & 0.08 & 0.10 & 0.15 & 0.13 & 0.08 & 0.01 & -0.32 & & & & & \\
\hline 12. Industry Concentration (home country) & 41.06 & 55.29 & -0.00 & -0.22 & -0.21 & 0.00 & 0.04 & 0.01 & -0.14 & -0.11 & -0.01 & 0.88 & -0.35 & & & & \\
\hline 13. Industry Dynamism (home country) & 1.01 & 0.01 & -0.02 & 0.07 & 0.06 & -0.01 & -0.03 & -0.02 & 0.06 & 0.09 & -0.03 & -0.47 & 0.16 & -0.43 & & & \\
\hline 14. Industry Munificence (home country) & 1.03 & 0.03 & -0.01 & 0.14 & 0.04 & 0.10 & 0.07 & 0.06 & -0.04 & -0.05 & -0.01 & 0.01 & 0.28 & -0.01 & -0.02 & & \\
\hline 15. Intra-regional Geographic Diversification & 0.13 & 0.22 & -0.11 & 0.08 & 0.15 & 0.21 & 0.33 & 0.13 & 0.65 & 0.39 & 0.06 & -0.12 & 0.11 & -0.13 & 0.06 & -0.03 & \\
\hline 16. Inter-regional Geographic Diversification & 0.20 & 0.35 & -0.08 & 0.04 & 0.19 & 0.18 & 0.25 & 0.13 & 0.83 & 0.54 & 0.09 & -0.09 & 0.10 & -0.12 & 0.06 & -0.04 & 0.70 \\
\hline
\end{tabular}

Note: $\mathrm{N}=2,686$ observations of 680 born-globals established in 2002, 2003, or 2004 and followed until 2010. Correlations with values of $|.04|$ or greater are significant at $\mathrm{p}<$ 0.05 . 
Table 5

Cox Regression Estimates

\begin{tabular}{|c|c|c|c|c|c|}
\hline & Model 1 & Model 2 & Model 3 & Model 4 & Model 5 \\
\hline \multirow[t]{2}{*}{ Medium High-Tech Dummy } & 0.89 & 0.89 & 0.89 & 0.89 & 0.89 \\
\hline & $(0.14)$ & $(0.14)$ & $(0.14)$ & $(0.14)$ & $(0.14)$ \\
\hline \multirow[t]{2}{*}{ High-Tech Dummy } & 1.07 & 1.02 & 1.02 & 1.01 & 1.01 \\
\hline & $(0.17)$ & $(0.17)$ & $(0.17)$ & $(0.17)$ & $(0.16)$ \\
\hline \multirow[t]{2}{*}{ Cohort Dummy (2003) } & 1.13 & 1.14 & 1.14 & 1.14 & 1.14 \\
\hline & $(0.11)$ & $(0.11)$ & $(0.11)$ & $(0.11)$ & $(0.11)$ \\
\hline \multirow[t]{2}{*}{ Cohort Dummy (2004) } & $0.78 *$ & $0.78^{*}$ & $0.78 *$ & $0.78 *$ & $0.78 *$ \\
\hline & $(0.12)$ & $(0.12)$ & $(0.12)$ & $(0.12)$ & $(0.12)$ \\
\hline \multirow[t]{2}{*}{ Operating Profits } & $1.00 * *$ & $1.00 * *$ & $1.00 * *$ & $1.00 * *$ & $1.00 * *$ \\
\hline & $(0.00)$ & $(0.00)$ & $(0.00)$ & $(0.00)$ & $(0.00)$ \\
\hline \multirow[t]{2}{*}{ Sales } & $1.00 * * *$ & $1.00 * * *$ & $1.00 * * *$ & $1.00 * * *$ & $1.00 * * *$ \\
\hline & $(0.00)$ & $(0.00)$ & $(0.00)$ & $(0.00)$ & $(0.00)$ \\
\hline \multirow[t]{2}{*}{ International Experience } & $0.83 \dagger$ & $0.83 \dagger$ & $0.83 \dagger$ & $0.83 \dagger$ & $0.83 \dagger$ \\
\hline & $(0.11)$ & $(0.11)$ & $(0.11)$ & $(0.11)$ & $(0.11)$ \\
\hline \multirow[t]{2}{*}{ Internationalization Speed } & $0.74 * * *$ & $0.63 * * *$ & $0.62 * * *$ & $0.63 * * *$ & $0.62 * * *$ \\
\hline & $(0.07)$ & $(0.09)$ & $(0.09)$ & $(0.09)$ & $(0.09)$ \\
\hline \multirow[t]{2}{*}{ Geographic Distance } & 1.00 & 1.00 & 1.00 & 1.00 & 1.00 \\
\hline & $(0.00)$ & $(0.00)$ & $(0.00)$ & $(0.00)$ & $(0.00)$ \\
\hline \multirow[t]{2}{*}{ World Industry Trade Volume } & 1.18 & 1.18 & 1.17 & 1.17 & 1.16 \\
\hline & $(0.12)$ & $(0.12)$ & $(0.12)$ & $(0.12)$ & $(0.12)$ \\
\hline \multirow[t]{2}{*}{ Mills Ratio Merger } & 0.74 & 0.82 & 0.81 & 0.81 & 0.81 \\
\hline & $(0.39)$ & $(0.44)$ & $(0.44)$ & $(0.45)$ & $(0.45)$ \\
\hline \multirow[t]{2}{*}{ Mills Ratio Split } & 1.27 & 1.15 & 1.16 & 1.15 & 1.16 \\
\hline & $(0.36)$ & $(0.41)$ & $(0.41)$ & $(0.42)$ & $(0.41)$ \\
\hline \multirow[t]{2}{*}{ Industry Density } & 1.00 & 1.00 & 1.00 & 1.00 & 1.00 \\
\hline & $(0.00)$ & $(0.00)$ & $(0.00)$ & $(0.00)$ & $(0.00)$ \\
\hline \multirow[t]{2}{*}{ Industry Competitor Size } & 1.04 & 1.05 & 1.05 & 1.05 & 1.05 \\
\hline & $(0.05)$ & $(0.05)$ & $(0.05)$ & $(0.05)$ & $(0.05)$ \\
\hline \multirow[t]{2}{*}{ Industry Concentration } & 1.00 & 1.00 & 1.00 & 1.00 & 1.00 \\
\hline & $(0.00)$ & $(0.00)$ & $(0.00)$ & $(0.00)$ & $(0.00)$ \\
\hline \multirow[t]{2}{*}{ Industry Dynamism (home country) } & 0.94 & 0.93 & $0.89 \dagger$ & 0.93 & $0.89 \dagger$ \\
\hline & $(0.06)$ & $(0.07)$ & $(0.07)$ & $(0.07)$ & $(0.07)$ \\
\hline \multirow[t]{2}{*}{ Industry Munificence (home country) } & 1.06 & 1.06 & 1.06 & 1.08 & 1.08 \\
\hline & $(0.07)$ & $(0.07)$ & $(0.07)$ & $(0.07)$ & $(0.07)$ \\
\hline \multirow[t]{2}{*}{ Intra-regional Geographic Diversification } & & $0.80^{*}$ & $0.79 * *$ & $0.81 *$ & $0.80 * *$ \\
\hline & & $(0.08)$ & $(0.08)$ & $(0.08)$ & $(0.08)$ \\
\hline \multirow[t]{2}{*}{ Inter-regional Geographic Diversification } & & $1.31 * *$ & $1.31 * *$ & $1.31 * *$ & $1.31 * *$ \\
\hline & & $(0.08)$ & $(0.08)$ & $(0.08)$ & $(0.08)$ \\
\hline \multirow[t]{2}{*}{ Intra-regional Geographic Diversification $\times$ Industry Dynamism } & & & $0.77 * *$ & & $0.78 * *$ \\
\hline & & & $(0.09)$ & & $(0.09)$ \\
\hline \multirow[t]{2}{*}{ Inter-regional Geographic Diversification $\times$ Industry Munificence } & & & & $1.11 \dagger$ & $1.11 \dagger$ \\
\hline & & & & $(0.06)$ & $(0.06)$ \\
\hline Log-likelihood & $-2,139.67$ & $-2,132.87$ & $-2,131.52$ & $-2,132.07$ & $-2,130.70$ \\
\hline Chi-square & 102.97 & 122.68 & 140.14 & 124.91 & 144.20 \\
\hline$N$ & 2,686 & 2,686 & $2,686.00$ & 2,686 & 2,686 \\
\hline Number of Firms & 680 & 680 & 680 & 680 & 680 \\
\hline
\end{tabular}

Notes. Hazard ratio reported; clustered standard errors are in parentheses.

$\mathrm{N}=2,686$ observations of 680 born-globals established in 2002, 2003, or 2004 and followed until 2010.

$\dagger p<0.1 ; * p<0.05 ; * * p<0.01 ; * * * p<0.001$ 
Figure 1

Interaction Effect of Intraregional Geographic Diversification and Home Country Environmental Dynamism

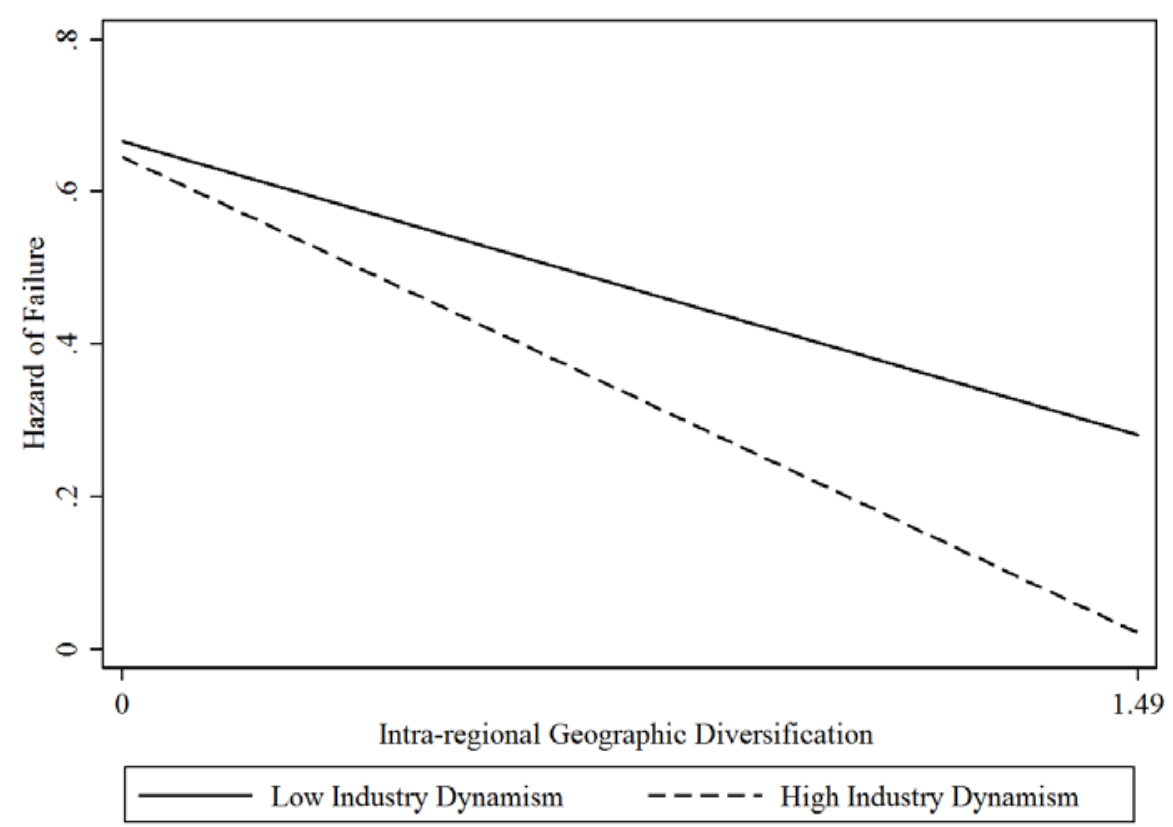

Figure 2

Interaction Effect of Interregional Geographic Diversification and Home Country Environmental Munificence

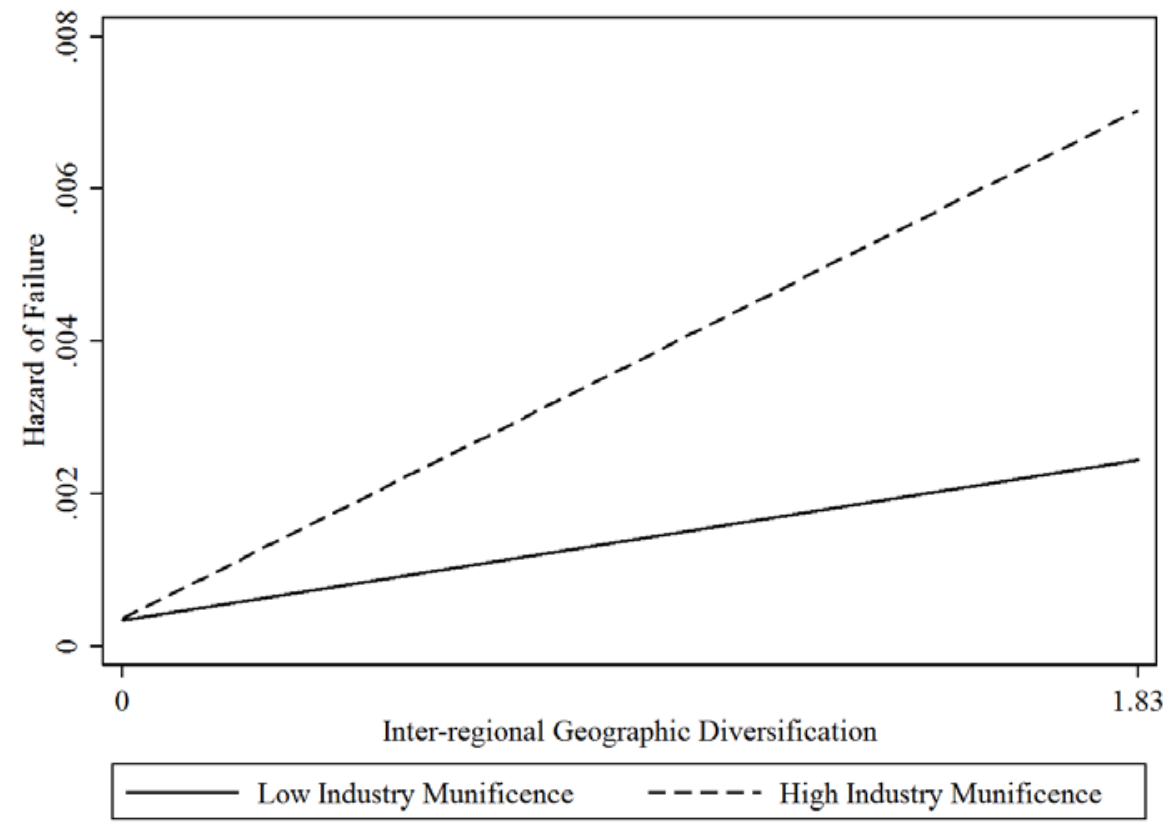


${ }^{\mathrm{i}}$ The aim of managing failure risk is to reduce the costs of internationalization while remaining cognizant of the local industry conditions that may facilitate exploration in different regions versus exploitation in a region. While we do not rely on an organizational learning framework to develop the hypotheses on moderation effects, the exploration-exploitation framework provides a useful lens to assess home industry-export strategy fit. When home industry dynamism is greater, born-globals can "exploit" a region to mitigate competitive pressures in home industry. Conversely, when home industry is munificent, bornglobals can "explore" across regions, as they do not face immediate survival pressures and could focus on long-term competitive positioning. We thank an anonymous reviewer for pointing out this alternative interpretation.

ii We conducted robustness tests by using the non-orthogonalized variables, and the results did not change significantly.

iii The culture-based regional grouping scheme adapted from the general scheme used by Gupta, Hanges, and Dorfman (2002) includes the following groupings (in capitals) and countries: ANGLO: Australia, Canada, Ireland, New Zealand, South Africa, and the United Kingdom; ARAB: Egypt, Kuwait, Morocco, Qatar, and Turkey; CONFUCIAN ASIA: China, Hong Kong, Japan, Singapore, and South Korea; EASTERN EUROPE: Albania, Greece, Hungary, Poland, Russian Federation, and Slovenia; EUROPEAN NORDIC: Denmark, Finland, and Sweden; GERMANIC: Austria, Germany, and the Netherlands; LATIN AMERICA: Argentina, Brazil, Colombia, Costa Rica, Ecuador, El Salvador, Guatemala, Mexico, and Venezuela; SOUTHERN EUROPE: France, Israel, Italy, Portugal, Spain, and Switzerland; SOUTHERN ASIA: India, Indonesia, Iran, Malaysia, Philippines, and Thailand; SUB-SAHARA AFRICA: Namibia, Nigeria, and Zambia. The trade- and investment-based regional grouping scheme adapted from the general scheme used by Donnenfeld (2003) includes the following groupings (in capitals) and countries: ANDEAN: Chile, Colombia, Ecuador, and Peru; ASEAN: Indonesia, Malaysia, Philippines, Singapore, and Thailand; EU: Austria, Belgium, Denmark, Finland, France, Germany, Greece, Ireland, Italy, Luxembourg, the Netherlands, Portugal, Spain, and Sweden; MERCOSUR: Argentina, Brazil, and Uruguay; NAFTA: Canada and Mexico; PAN-ARAB: Bahrain, Egypt, Iraq, Jordan, Kuwait, Lebanon, Libya, Morocco, Oman, Qatar, Saudi Arabia, Sudan, Syria, Tunisia, United Arab Emirates, and Yemen. 